\title{
Transformation of the Specialized Knowledge of Future Primary Teachers on Fraction Division
}

\author{
M. Valenzuela-Molina iD a \\ E. Ramos-Rodríguez iD b \\ P. Flores ${ }^{D} \mathrm{c}$ \\ ${ }^{a}$ Universidad Alberto Hurtado, Facultad de Educación, Santiago, Chile \\ ${ }^{\mathrm{b}}$ Pontificia Universidad Católica de Valparaíso, Facultad de Ciencias, Instituto de Matemática, Chile \\ ${ }^{\mathrm{c}}$ Universidad de Granada, Facultad de Ciencias de la Educación, Departamento de Didáctica de la \\ Matemática, Granada, España
}

Received for publication 20 Jan. 2020. Accepted after review 5 May 2020

Designated editor: Claudia Lisete Oliveira Groenwald

\begin{abstract}
Background: an important field of research in mathematics education is the initial training of teachers where deficiencies in the disciplinary and didactic knowledge required for their profession can be evidenced. Objective: To study the transformation of the specialized knowledge of future teachers about division of fractions. Design: qualitative descriptive paradigm where a case study is approached. Context and participants: a group of three students who design, reformulate and implement mathematical tasks during their initial training in a Lesson Study environment using the Didactic Analysis method, where they receive feedback from their peers and trainer. Data collection and analysis: data collection is obtained from the written productions of future teachers and the record of recordings of class discussions, which were analyzed using the content analysis method and the categories of the specialized knowledge model. from the math teacher. Results: future teachers show a change in their knowledge, starting their process with the design of a problem situation with a different meaning in the conceptual field of division of fractions, which becomes a problem situation with a multiplicative structure of the type "isomorphism of measure". Conclusions: deepening the processes of transformation of the specialized knowledge of future teachers from their first formative stage can give us insights on how to improve their training aiming at their professional teaching development.
\end{abstract}

Keywords: Didactics; Mathematics teaching; teacher training; division; fractions.

Corresponding author: Macarena Valenzuela-Molina. Email: mvalenzuelamolina@gmail.com 


\section{Transformação de conhecimento especializado de futuros professores sobre divisão de fração}

\section{RESUMO}

Contexto: um importante campo de investigação em educação matemática é a formação inicial de professores onde se evidenciam deficiências nos conhecimentos disciplinares e didáticos necessários à sua profissão. Objetivo: Estudar a transformação do conhecimento especializado dos futuros professores sobre a divisão de frações. Design: paradigma qualitativo descritivo onde se aborda um estudo de caso. Contexto e participantes: um grupo de três alunos que projetam, reformulam e implementam tarefas matemáticas durante seu treinamento inicial em um ambiente de Estudo de Classe usando o método de Análise Didática, onde recebem feedback de seus colegas e do treinador. Coleta e análise de dados: a coleta de dados é obtida a partir das produções escritas dos futuros professores e do registro das gravações das discussões das aulas, as quais foram analisadas por meio do método de análise de conteúdo e das categorias do modelo de conhecimento especializado, do professor de matemática. Resultados: os futuros professores apresentam uma mudança em seus conhecimentos, iniciando seu processo com o desenho de uma situação-problema com um significado diferente no campo conceitual da divisão de frações, que se torna uma situaçãoproblema com uma estrutura multiplicativa do tipo "isomorfismo de medida " Conclusões: o aprofundamento dos processos de transformação dos saberes especializados dos futuros professores desde a sua primeira fase formativa pode nos dar subsídios sobre como melhorar a sua formação visando o seu desenvolvimento profissional docente. frações.

Palavras-chave: didática; matemática; formação de professores; divisão;

\section{INTRODUCTION}

Teacher training is a relevant field of research in mathematics education. The numerous international mathematics teacher education handbooks on the subject (Clements, Bishop, Keitel-Kreidt, Kilpatrick, \& Leung, 2013; English, $\&$ Kirshner, 2015), and the TEDS-M study (international study on beginning teacher training in mathematics) show the relevance that this line of research has had in recent years (Sanz, \& Martín, 2014).

In this scenario, the design of mathematical school tasks is an appropriate context for the diagnostic of mathematics knowledge teaching of elementary education future teachers (FT). This context can help us highlight the mathematical and teaching aspects that arise when the future teachers propose tasks for their students to achieve an expected level of learning. In this case, we will analyse the fractions' multiplicative structure as a mathematical 
object, focusing on those problem situations involving a division of fractions or division of a fraction by a natural number.

The division of fractions was chosen as the object of this study due to the complexity it entails for teachers in their teaching, and to students in their learning (Moriel, 2014), since both groups consider it a mechanical and nonsense operation (Ma, 2010; Moriel, 2019; Olanoff, 2011; Özel, 2013; Payne, 1976; Tiroch, 2000). Also supporting our choice are the findings from some previous research (Ramos-Rodríguez, Reyes-Santander \& Valenzuela-Molina, 2017; Valenzuela \& Ramos-Rodríguez, 2018), showing a precarious appropriation of the division of fractions in teachers initial training in the context of this study.

Another inspiring study is Ma's (2010). Although she investigates teachers in practice, her findings are attractive when they reveal the considerable differences between countries, by asking classroom teachers to bring situations for the division of fractions given by $1 \frac{3}{4}: \frac{1}{2}$, showing a problem in the coherence between the situation raised by the teachers and the division of fractions provided. Besides Ma (2010), we have the research works by Contreras (2012) and Liñán et al. (2014), who have deepened knowledge about the elementary school teacher as they solved problematic situations involving the division of fractions, showing the weaknesses in their procedural resolution.

Therefore, several studies detected conceptual and procedural weaknesses concerning the mathematical and pedagogical knowledge of future teachers of elementary education on fraction division and deeper weaknesses concerning the multiplicative structure. In this context (Blömeke, Suhl, \& Kaiser, 2011; Ramos-Rodríguez, Reyes-Santander, \& Valenzuela-Molina, 2017), this research work aimed to study the transformation of specialized knowledge in the division of fractions, and how the future teachers designed, restructured and implemented the mathematical tasks during their formation process.

\section{THEORETICAL FRAMEWORK}

The theoretical background of this study was mainly the Mathematics Teacher Specialized Knowledge model (MTSK). This work also examined the concept of transformation that underlies this objective so that we could take a stand regarding the idea of transformation of knowledge. Finally, we carry out 
a conceptual analysis of the multiplicative structure, aiming to understand the mathematical and teaching knowledge highlighted and the transformations that this entails.

\section{Multiplicative Structure}

The study of the multiplicative structure begins with Nescher (1992) and Vergnaud (1990; 1997), who categorized the various strategies that boys and girls who attend different schools use to solve problems in different types of multiplicative situations. From the previous research works, perspectives of analysis, reflection, and discussion arise on the categories of multiplicative problems in which a multiplication or a division intervenes. With these, a multiplicative structure constituted of concepts, procedures, and representations, which Vergnaud (1983) calls conceptual fields.

According to Vergnaud, (1997), three types of problem situations categorize the multiplicative structures: a) isomorphism of measures, b) a single measure space, and c) product of measures, which we show below in detail.

\section{a) Isomorphism of measures}

The quaternary relationship of the isomorphism of measures generates four types of problems, and the division of fractions may be present in all of them. The first is the multiplication problems, in which the unknown is the total number of objects or elements sought. The second, the partitive division problems, in which the unknown is the quotient or number of objects per group (Contreras, 2012; Liñán et al., 2014), do not make sense for the fractions, because the distribution must always be done in whole number (Flores, 2018). The third type is the measurement (or quotitive) division problems, in which the unknown is the divisor or the number of groups of a given measure. Finally, the rule of three problems, involving multiplication and division (Vergnaud, 1997).

\section{b) A single measure space}

In a single measure space there is a relationship between two quantities of the same magnitude (or measure space) that are affected by a scalar, which is generally designated by the linguistic expression "times." This kind of problem situation appears in three different ways. The first case involves a 
multiplication, where the unknown is the compared quantity, that is, the result of multiplying the quantity of "times" that the scalar is compared with the referent magnitude. The second case involves a division to find the unknown corresponding to the referent, that is, when the magnitude to be compared is not known. The last case also involves a division, and the unknown quantity is the scalar, that is, the quantity of "times" that the referent measure must be compared.

\section{c) Product of measures}

The product of measurements is formed by the relation of three quantities, of which one is the product of the other two, both numerically and dimensionally (Vergnaud, 1997). Greer (1992) and Nescher (1992) named this type of situation a Cartesian product. The unknown may be the product between both measurements, which implies a multiplication. If the unknown quantity is either measure, solving the situation involves division.

\section{Division of fractions and division of a fraction in a natural number}

The multiplicative structure of fractions implies division in all types of problems presented by Vergnaud (1983). Because division of fraction is our object of study, we present examples of the situations involving division below.

\section{Table 1}

Situations involving division in the multiplicative structure of Vergnaud (1997)

\begin{tabular}{|c|c|c|c|}
\hline Multiplicative & Example of situation & \multicolumn{2}{|c|}{ Unknown } \\
\hline \multirow{5}{*}{$\begin{array}{l}\text { Isomorphism } \\
\text { of measures }\end{array}$} & \multirow{4}{*}{$\begin{array}{l}\text { Partitive division (sharing) } \\
\text { You have to share } 1 \text { whole } 3 / 41 \text { of } \\
\text { a drink to } 7 \text { people. How much of } \\
\text { the beverage does each of them } \\
\text { get? } \\
\text { Important: }\end{array}$} & \multirow{2}{*}{\multicolumn{2}{|c|}{$\begin{array}{c}\text { The unknown is the unit } \\
\text { value }\end{array}$}} \\
\hline & & & \\
\hline & & People & $\begin{array}{c}\text { Liter } \\
\text { of a } \\
\text { drink }\end{array}$ \\
\hline & & 1 & $\mathrm{x}$ \\
\hline & & 7 & $13 / 41$ \\
\hline 222 & Acta Sci. (Canoas), 23(3), 218-240, & n. 2021 & \\
\hline
\end{tabular}




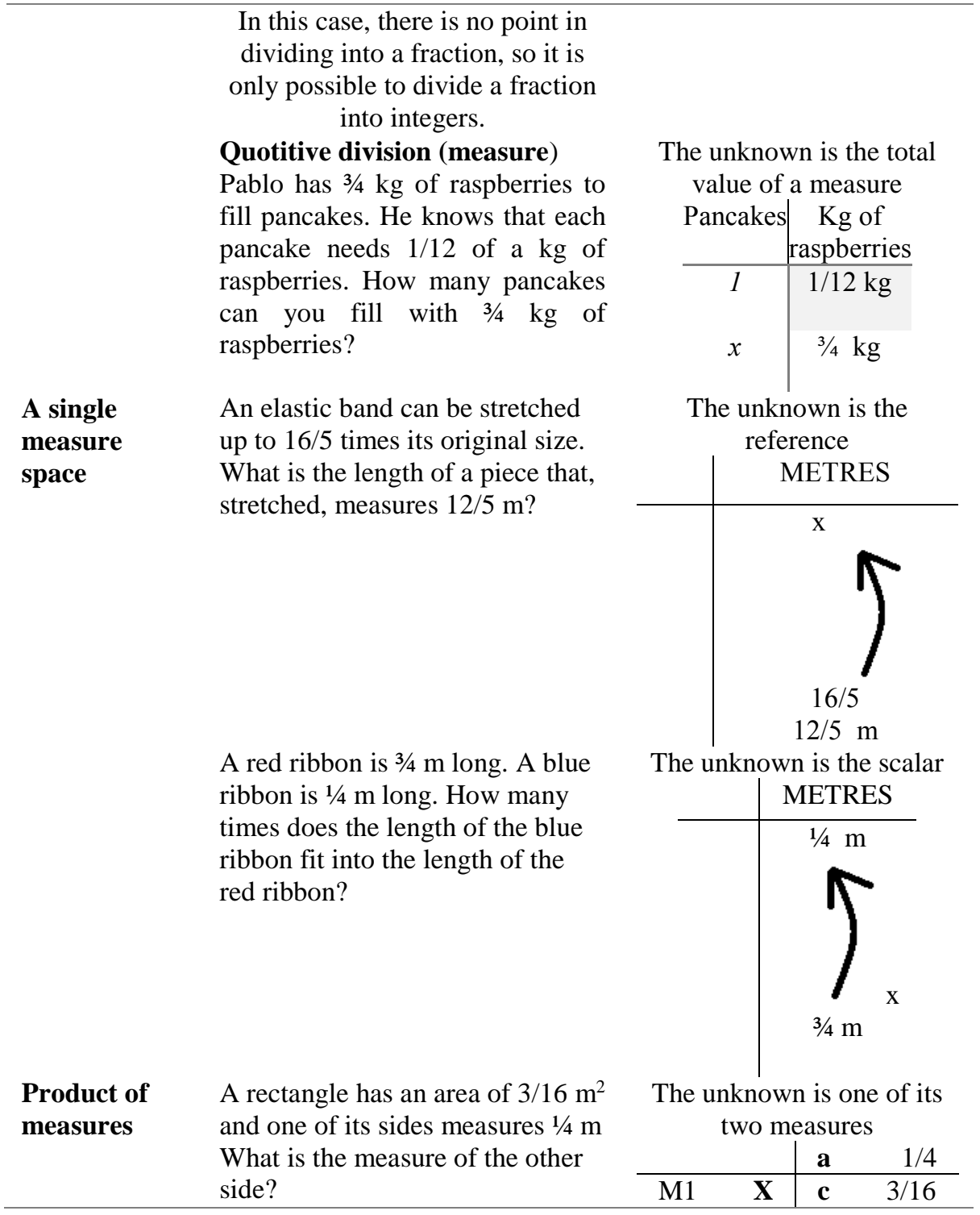

\section{Mathematics teacher knowledge}

The origin of the study of teacher knowledge is found on the basal ideas of Shulman (1986), who delves into the teacher Pedagogical Content Knowledge, such as the knowledge all teachers use when teaching a specific 
discipline content. These studies give rise to several models of teacher knowledge. In this work, we focus on the MTSK model (Carrillo et al., 2018), which is presented through the components outlined in Figure 1.

\section{Figura 1}

MTSK model (Carrillo et al., 2018, p.7)

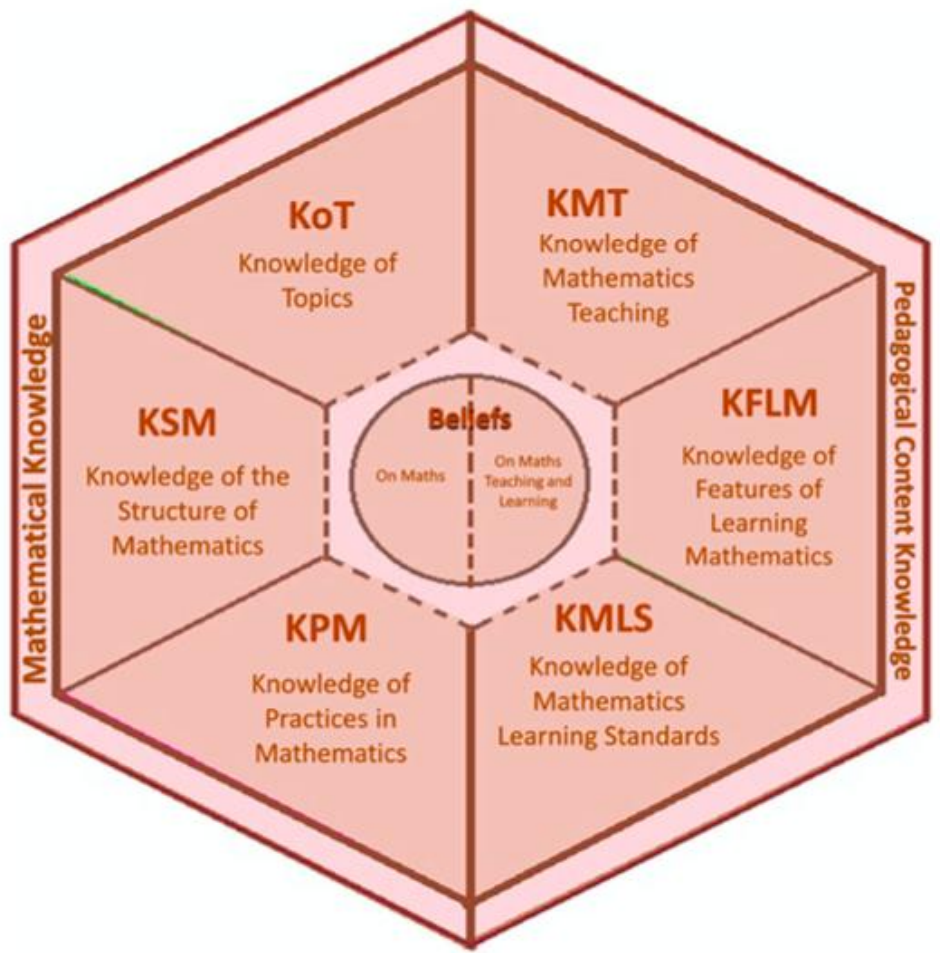

In Figure 1, two great domains can be visualized, the mathematical knowledge (MK), which plays an articulating role with the entire model, and the pedagogical mathematical content knowledge (PCK), which delves into the mathematical content, when there is teaching and learning intention. Beliefs about mathematics, relating to MK, and beliefs about mathematics teaching and learning, relating to PCK, also appear in the centre of the figure (Carrillo et al., 2018). Each of the MTSK domains is divided into three sub-domains, as distinguished below. 
The domain of mathematics knowledge (MK) considers: a) the knowledge of topics (KoT), deepening the subject to be taught and its level of organization and depth; b) the knowledge of the structure of mathematics (KSM), which includes knowledge of different mathematical objects and their connections with each other; and c) the knowledge of the practice in mathematics (KPM), defined " that mathematical activity that constitutes a pillar in mathematical creation and that has a logical support that allows us to abstract rules for it " (Flores-Medrano, 2016, p. 30).

The domain of the pedagogical mathematics content knowledge (PCK) consists of: a) the knowledge of mathematics teaching (KMT), which characterizes the teaching of content, teaching theories, teaching resources, strategies, techniques, tasks, and examples (Escudero, Contreras \& Vasco, 2016); b) the knowledge of features of learning mathematics (KFLM), such as skills of analysis of students' productions, identifying difficulties and errors; and c) the knowledge of mathematics learning standards (KMLS), focusing the curriculum, at a level of conceptual and procedural development expected for a topic at a certain level.

From this perspective of the specialized knowledge of the mathematics teacher's, we have considered the knowledge of the topics (KoT), and the knowledge of mathematics teaching (KMT) as sub-domains to be analysed in the students' productions.

In the first instance, the KoT considers the domain of mathematics to be taught from an organization, deepening, and structuring higher than the students will learn at school, consisting in knowledge of mathematical structures, such as concepts and definitions; knowledge of the meanings from the phenomenology and the contexts that make sense of mathematics; and from the different representations of the mathematical objects for a better understanding from various dimensions. From these three specific types of knowledge of the KoT, we focus on phenomenology and mathematical structure.

Subsequently, we consider the KMT, which takes into account the characteristics of teaching of the content, such as the knowledge of teaching theories, of the specific teaching resources for a topic, of the strategies, techniques, and tasks, all this referring to the mathematical content to be worked. In this study, and due to the nature of the data, we focus on the strategies, techniques, and tasks the future teachers presented in their lesson plans. 


\section{Initial professional development from knowledge transformation}

One of the first approaches to the concept of knowledge transformation from the MTSK was by Ribeiro (2010), who, by investigating two future teachers, identified what he named an "evolution of their professional knowledge", in the sense of "back to basics," i.e., not doing like they did before, but to take consciousness and readjust their practices.

Another relevant study in this line is Flores-Medrano (2015) doctoral thesis, who uses the concept of "knowledge transformation" from the standpoint of how to reconcile knowledge with another existing knowledge. In our study, we will use the concept of "transformation" in the same way, by considering tasks in which an initial knowledge is evidenced, which is consciously modified and transformed into new knowledge by having them redesigned after discussions and feedbacks in a given formative space.

From another standpoint, we consider Sfard's sociocultural perspective (2008), understanding learning as a gradual transition from what an individual is capable of doing or knowing collectively to what he/she is capable of doing or knowing by him/herself (Escudero, Gavilán \& Sánchez-Matamoros, 2014), which allows him/her to make transformations that give rise to new knowledge.

We complement the ideas of Flores-Medrano (2015), Ribeiro (2010), and Sfard (2008) with the definition of transformation presented by the Royal Spanish Academy (RAE). It defines transformation as to make someone or something change shape, transmute something into something else. In this way, we suggest that the "teacher's knowledge transformation" (the future teachers') can be verified when they manifest gradual changes in what they are capable of doing with others and individually, influenced by external agents, taking consciousness about the new ideas or the changes that are generated for the readjustment of their practice. In our case, we sustain that the future teachers showed their transformation in the MTSK when they, at different stages of their formation, changed the design, redesign, and implementation of mathematical tasks on a specific topic. This action revealed that they take consciousness about the changes implemented to help their students achieve learning, evidencing that they improved their specialized mathematics knowledge.

An MTSK transformation is manifested when teachers restructure their specialized knowledge to move on from an initial MTSK to an ideal MTSK. In other words, the initial MTSK is restructured in what to do and how to do it. It 
is crucial to say that we are not referring to a final MTSK, as it is always in constant transformation.

\section{RESEARCH METHODOLOGY}

This research is descriptive and qualitative (Hernández, Fernández, \& Baptista, 2010). It aims to study the transformation of the specialized knowledge of future teachers of elementary education about the division of fractions when designing, reformulating and implementing mathematical tasks during a formative process.

The participants are in future teachers' formation to teach elementary education in Chile, a general formation with a degree in a specific teaching area, in our study, mathematics teaching. The degree they obtain allows them to work with courses from the 1 st to the 8 th grade of elementary school (students between 6 and 13 years old), teaching all subject matters. In this context, we carry out a case study (Stake, 2003) with three future teachers' process in the fourth grade of a degree course (which lasts five years).

The data were collected in the four stages of a subject, where the future teacher's designed and refined a class, based on different formation devices that allowed them to expand their knowledge: didactic analysis (Rico, Lupiáñez y Molina, 2013); observations and trainer's feedbacks; reflections about the implementation of the task in the classroom, and the final discussion with the peers and the future teachers about the class. Figure 2 illustrates this process.

\section{Figure 2}

MTSK transformation model (own elaboration)

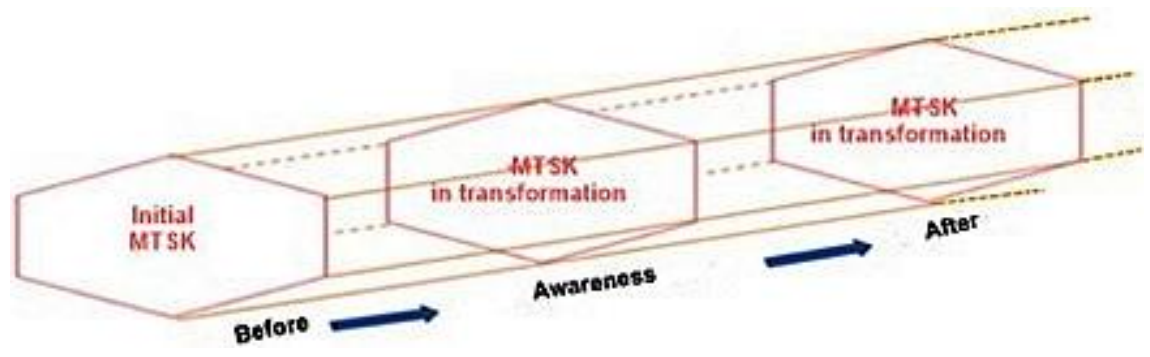




\section{Figure 3}

Planning stages of a class

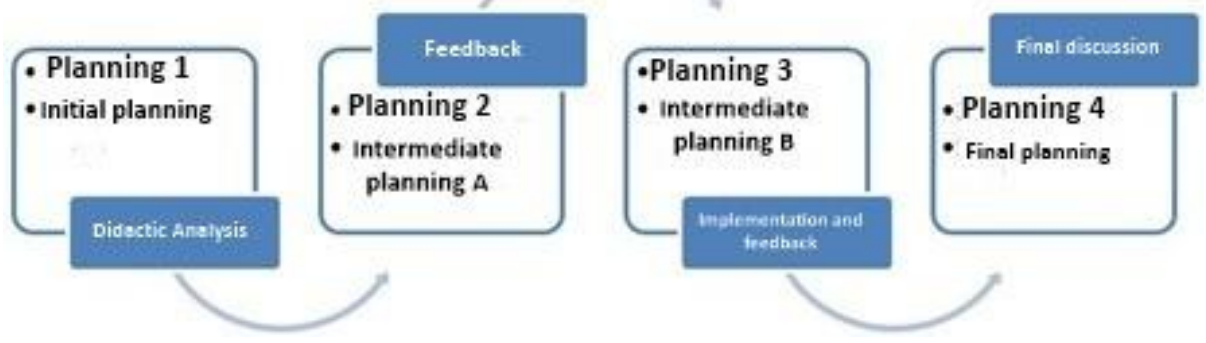

We obtained the data from the lesson plans proposed by the future teachers in each stage, the transcripts of the video recordings of the sessions, and feedbacks, when the group presents its proposals.

The study is based on the content analysis method (Flick, 2004), in which the units of analysis correspond, in the case of the future teachers' lesson plans, to each of the statements of the school tasks they proposed. In the case of video transcripts, the unit of analysis corresponds to each intervention of the future teacher's or trainer in the classes where they present their progress. In both cases, common ideas and texts are analysed according to the concepts worked from our object of study, based on the multiplicative structure that involves the division of fractions.

Considering the MTSK model, we established descriptors to identify knowledge and its transformation, emerging a list of indicators proposed in Table 2. In particular, elements of two subdomains are highlighted, one from the mathematical domain, knowledge of themes (KoT), and the other from the pedagogical content knowledge, knowledge of the mathematics teaching (KMT), related to the multiplicative structure that implies division of fractions. We selected two KoT and KMT domains for this report, to identify the relationships between them, indications that can help us with the analysis with other domains in subsequent studies. 


\section{Table 2}

Categories of analysis from some elements of the KoT (structure and contexts) and from the KMT (strategies, techniques, and tasks) associated with the division of fractions.

\begin{tabular}{|c|c|c|}
\hline Category & Description & Indicator \\
\hline C. 1 & C.1.1 & C.1.1.1 \\
\hline $\begin{array}{l}\text { Phenomenology's } \\
\text { (KoT) }\end{array}$ & $\begin{array}{l}\text { Contextualization } \\
\text { of the problem } \\
\text { situation }\end{array}$ & $\begin{array}{l}\text { Designs situation in a personal close } \\
\text { context } \\
\text { C.1.1.2 } \\
\text { Designs situation in a social context } \\
\text { C.1.1.3 } \\
\text { Designs situation in scientific context } \\
\text { C.1.1.4 } \\
\text { Designs situation in a mathematical } \\
\text { context }\end{array}$ \\
\hline C. 2 & C. 2.1 & C.2.1.1 \\
\hline $\begin{array}{l}\text { Meanings } \\
\text { according the } \\
\text { Multiplicative } \\
\text { structure situation } \\
\text { (KoT) }\end{array}$ & $\begin{array}{l}\text { Isomorphism of } \\
\text { measures }\end{array}$ & $\begin{array}{l}\text { Designs a situation involving a staring } \\
\text { division } \\
\text { C.2.1.2 } \\
\text { Designs a situation involving a measure } \\
\text { division }\end{array}$ \\
\hline & C. 2.2 & C.2.2.1 \\
\hline & $\begin{array}{l}\text { A single measure } \\
\text { space }\end{array}$ & $\begin{array}{l}\text { Designs a situation with an unknown in } \\
\text { the referent } \\
\text { C.2.2.2 } \\
\text { Designs a situation with unknown in } \\
\text { the scalar }\end{array}$ \\
\hline & C. 2.3 & C.2.3.1 \\
\hline & $\begin{array}{l}\text { Product of } \\
\text { measures }\end{array}$ & $\begin{array}{l}\text { Designs situation with unknown in any } \\
\text { of its two measures }\end{array}$ \\
\hline C. 3 & C.3.1 Tasks & C.3.1.1 \\
\hline $\begin{array}{l}\text { The strategies } \\
\text { techniques and } \\
\text { tasks for teaching } \\
\text { a content (KMT) }\end{array}$ & & $\begin{array}{l}\text { Proposes tasks appropriate to the level } \\
\text { according to the use of symbols with } \\
\text { meanings } \\
\text { C. } 3.1 .2 \\
\text { Proposes learning sequences that allow } \\
\text { us to move between the different } \\
\text { systems of representation, a possible } \\
\text { sequence can be from the concrete, } \\
\text { pictorial and symbolic for the division } \\
\text { of fractions. }\end{array}$ \\
\hline
\end{tabular}


Proposes tasks for diversity in the way of learning the division of fractions.

\section{RESULTS AND ANALYSIS}

At the beginning of the formative process, the trainer asks the future teachers to identify a problem in the teaching of fractions. So, the future teachers point out as a problem the adverse aspects of the mechanization of the cross-product algorithm for the division of fractions. They select a class' objective and a specific level of teaching and begin this planning process. In this study, we will focus on the analysis of the future teachers' main task statements, which transforms as their formation advances (Figure 2). Table 3 shows the details of this progress.

\section{Table 3}

Progress of statements of the central mathematical task of the class.

\begin{tabular}{|c|c|c|c|}
\hline $\begin{array}{l}\text { Task } T_{1.1} \\
\text { of planning P1.1 }\end{array}$ & $\begin{array}{l}\text { Task } T_{1.2} \text { of } \\
\text { planning } P_{1.2}\end{array}$ & $\begin{array}{l}\text { Task T1.3 of planning } \\
P_{1.3}\end{array}$ & $\begin{array}{l}\text { Task T1.4 of planning } \\
\text { P1.4 }_{1.4}\end{array}$ \\
\hline $\begin{array}{l}\text { Pablo has } 3 / 4 \text { of } \\
\text { raspberries to fill } \\
\text { pancakes. He knows } \\
\text { that each pancake } \\
\text { needs } 3 / 2 \text { of the } \\
\text { raspberries he has. } \\
\text { How many pancakes } \\
\text { can he fill with the } \\
\text { raspberries? }\end{array}$ & $\begin{array}{l}\text { A red ribbon is } \frac{3}{4} \mathrm{~m} \\
\text { long. A blue ribbon } \\
\text { is } \frac{3}{2} \mathrm{~m} \text { long. How } \\
\text { many times does } \\
\text { the length of the } \\
\text { blue ribbon fit into } \\
\text { the length of the } \\
\text { red ribbon? }\end{array}$ & $\begin{array}{l}\text { One yellow ribbon is } 4 \\
\text { meters long and another } \\
\text { purple ribbon is } \frac{1}{2} \text { meter } \\
\text { long. How many times } \\
\text { does the length of the } \\
\text { purple ribbon fit into the } \\
\text { length of the yellow } \\
\text { ribbon? } \\
\text { You can use the ribbons } \\
\text { to solve the problem }\end{array}$ & $\begin{array}{l}\text { One yellow ribbon is } 4 \\
\text { units long and another } \\
\text { purple ribbon is } 1 / 2 \text { unit } \\
\text { long. How many times } \\
\text { does the length of the } \\
\text { purple ribbon fit into the } \\
\text { length of the yellow } \\
\text { ribbon? } \\
\text { You can use the ribbons } \\
\text { to solve the problem } \\
\text { (optional) }\end{array}$ \\
\hline
\end{tabular}

The changes the future teacher's made in the tasks statement respond to the different inputs given during their formation process, such as the development of the didactic analysis of the topic, and the continuous feedback from peers and trainer. For this research work, we selected two subdomains of analysis from the MTSK, the knowledge of the themes (KoT), and the knowledge of the mathematics teaching (KMT), according to the categories shown above. 


\section{Analysis from Knowledge of Topics (KoT)}

\section{a) Phenomenology}

From the phenomenology associated with contexts (C.1), for the statement of task $T_{1.1}$, the future teachers use their knowledge of situations of the personal context (C.1.1.1) for the division of fractions, with the preparation of food as an activity of the individual or family group.

The group decided to change the context after carrying out the didactic analysis of the division of fractions, where they studied the different contexts of the division of fractions. Thus, they changed the statement of task $\mathrm{T}_{1.2}$, bringing a more social context into the task (C. 1.1.2), for which they used implements that usually appear in work contexts, such as construction or sewing job. Both contexts are suitable for teaching.

\section{b) Meaning according Multiplicative structure situation (KoT)}

Considering the multiplicative structure of the fractions, from the isomorphism of measure (C.2.1), in which the unknown is the number of times contained in a given measure, in $\mathrm{T}_{1.1}$ and $\mathrm{T}_{1.2}$ statements the divisor's fraction is greater than the dividend's fraction, which prevents the division itself from making sense for the given context, since when asking how many times it fits, the interpretation of the division of fractions as a measure is given as measurement (C.2.1.2), in which the divisor's fraction must necessarily be less than the dividend's fraction (Contreras, 2012), which has not yet been changed between one and the other task.

From the task, it was not possible to discover the reason for the selection of the fractions, but by reading the excerpt of the dialogue in Figure 3 , between the statements of tasks $T_{1.2}$ and $T_{1.3}$ we can observe that the topic of the selection of fractions is not indifferent to the future teachers, because they are aware of how difficult it is for the students that the divisor is not contained in the dividend. However, they decided to keep those fractions in the $T_{1.2}$ statement, to change them in the $\mathrm{T}_{1.3}$ statement.

Another data considered for the analysis is extracted from an instance of work between the group and the future teachers that focuses on the revision of the statement of task $T_{1.2}$ put in evidence in the following transcripts. In this context, and based on feedback and discussions regarding the class in general, they stop to evaluate the selection of the fractions in the proposal of the statement for task $T_{1.2}$, originating the following discussion, where FT1 and FT2 correspond to two of the future teachers and F to the trainer. 
FT1: In other words, I think that perhaps you should start with something that "fits", that can fit more times inside a "something", because all the same the ribbon does not "fit", so one of the answers may be that it does not fit.

F: and then, would we have to change the fraction?

FT1: Yes

F: Now, how can you think it could be?

FT1: we had said that, after all, in the second fraction it would always have to be improper.

F1: What for?

FT1: To do the inverse... [Silence]

F: but we are not seeing the inverse yet, we are in the first class. Okay, but we are in the first class where our goal is to understand the division of fractions. We have not set an objective for it yet, but remember that we are seeing what the learning objective says and it says two things, one is that they understand through the pictorial and the other is that they use the multiplicative inverse, so there are two different things there.

FT2: so, for the first class, the second fraction [the divisor of the division] could not necessarily be anything

F: it depends on what the objective that we are going to set is. If we only aim for the student to understand the division of the fractions, it is not necessary to manipulate those quantities; rather, we want the student to understand [the division of fractions]. So, there the ribbon can be, for example, three-fourths of the ribbon, and the one that we are going to divide can be shorter, what we must see is that the total length of the ribbon coincides with the shorter ribbons [that the fraction of the longest ribbon contains exactly the fraction of the shorter ribbon]. So, how many times that fraction is going to be contained in the longest fraction.

FT2: I imagine that I have the ribbon, that I have the tiny ribbons that fall into this long one, and if, for example, the ribbon at the corner has one end left out, a bit of that ribbon [mentioning that the dividing fraction is not precisely contained in the dividend's fraction].

Previously, the future teachers' thoughts, the feedback, and the awareness with which they chose specific fractions were presented according 
to what they intended to achieve with their students, revealing the changes that occurred as each stage progresses. Thus, knowledge transformation became explicit.

From the multiplicative structure that implies division of fractions, in the statement of task $T_{1.1}$ a problem with discrete representation is evidenced, with the number of pancakes that can be filled. Subsequently, and after studying the different interpretations associated with the division of fractions (quantitative, partitive, continuous or discrete, of area or linear, etc.), the group proposes the statement of task $T_{1.2}$ of the quota type of measurement (C.2.1.2), with the use of a continuous linear problem of division of fractions, where they use ribbons that represent the continuous measure. This shows knowledge transformation, understand from the progression of the teaching of fractions from continuous representations over discrete ones, which are more complex for students to understand (Llinares \& Sánchez, 1988).

\section{c) Analysis from the knowledge of Mathematics Teaching (KMT)}

From the teaching of the division of fractions and their wealth, according to the tasks proposed and presented to both peers and trainer for discussion and feedback, we did not observe any changes from $T_{1.1}$ statement to $\mathrm{T}_{1.2}$ statement; therefore, we will focus on the changes that allowed task $\mathrm{T}_{1.3}$ to emerge, where there was transformation when compared with the previous version $T_{1.2}$. In the statements of $T_{1.1}$ and $T_{1.2}$, they consider a fraction whose dividend is a proper fraction of $3 / 4$ and the divisor is an improper fraction of $3 / 2$. Then, the statement of version $T_{1.3}$ considers the use of a division of fractions whose dividend is the natural number 4 and the divisor is a proper fraction of $1 / 2$ that just fits into the dividend.

This shows a transformation of the knowledge of the future teachers about the variety of fractions to consider (C.3.1.3) for the beginning of the teaching of the divisions of fractions, as observed in the dialogue of figure 3 , since the future teachers are aware of the type of fractions to consider, and in the statement of task $T_{1.3}$ they change them to achieve progressive learning, since the teaching of the division of fractions with a dividend with a natural number and a divisor with a type of proper fraction, a progression of teaching of fractions proposed by the text for the formation of elementary education teachers used in initial formation of teachers in Chile (Lewin, López, Martínez, Rojas, \& Zanocco, 2014). 


\section{CONCLUSIONS}

Our objective was to study the transformation of the specialized knowledge of future teachers of elementary education about division of fractions when designing, reformulating, and implementing mathematics tasks within a formative process. From the previous analysis, it is possible to identify progressive transformations from one task to another.

In KoT, we observe knowledge transformation concerning the use of different contexts for the division of fractions, both personal and social. From the knowledge of meanings of the multiplicative structures of isomorphism of measures, the situations proposed are of the "division of measure" type, starting from a discrete representation in $\mathrm{T}_{1.1}$, transforming into a continuous representation from T 1.2 onwards. This explains a change in the proposal from the awareness of the future teachers in the most relevant teaching progression to start the division of fractions (Llinares \& Sánchez, 1988).

For the KMT, we observed great improvement in the tasks proposed accordingly to the progression in the teaching of division of fractions, based on the type of - proper, improper, mixed, equal to the unit - fractions to be considered in the operation, according to the level of difficulty. This reveals a transformation of the KMT knowledge of future teachers, the improvement of the task proposed according to the type of fractions to consider, and the progression of their teaching in contexts of measures with continuous models.

Furthermore, it seems that the aspects that are transformed in the KoT impact on the KMT, since each time they delve into the mathematical content in this specific case, in the contexts and meanings of the division of fractions allow teachers to make decisions regarding the design to improve the tasks. This aspect is observed in the changes that occur from one task to another, where a KoT knowledge is made explicit and then manifested in the KMT. For example, in task $\mathrm{T}_{1.2}$, division of fraction is used meaning a continuous measure (KoT, C.2.1.2), which affects the richness of task $T_{1.3}$ when presenting a division of an integer in a proper fraction, whose dividend is just contained in the integer, and then change the unit of measurement to non-standardized in task $T_{1.4}$. Such aspects allow improving the progression in teaching the division of fractions (KMT), i.e., there is a transformation of the KoT and the KMT, and, consequently, of the MTSK, all this in function of the students' learning improvement.

In summary, we have achieved our research objective by showing transformations in the tasks proposed, changes that give guidelines on how to 
generate instances of real learning in university classrooms, which allow future teachers to become aware of how to teach mathematics. The advancements to establish indicators of specialized knowledge on the division of fractions in KoT and KMT come to support strategies or methodologies for initial teacher training.

The objective of this research is to continue the studies on the transformation of the mathematics teacher's specialized knowledge, its implications for their decision-making, and how these changes occur, to raise formative elements that may enable this evolution in this teacher training segment.

\section{ACKNOWLEDGMENTS}

We thank the Comisión Nacional de Investigación Científica y Tecnológica, CONICYT, Chile, Doctoral Scholarship for the Formation of Advanced Human Capital No. 21160315, and to the Agencia Nacional de Investigación y Desarrollo (ANID), Chile, FONDECYT INICIACION Project No. 11190553, Principles of effective professional development programs for mathematics teachers.

\section{AUTHORS' CONTRIBUTIONS STATEMENTS}

MVM made the main contribution to this article. ERR and PFM contributed by conducting a comprehensive review and improvement of the document and reviewing the research methodology, data analysis and triangulation of results.

\section{DATA AVAILABILITY STATEMENT}

The corresponding author, MVM, will make available the data that supports the results of this study, upon reasonable request. 


\section{REFERENCES}

Blömeke, S., Suhl, U., \& Kaiser, G. (2011). Teacher education effectiveness:

Quality and equity of future primary teachers' mathematics and mathematics pedagogical content knowledge. Journal of Teacher Education, 62(2), 154-171. https://doi.org/10.1177/0022487110386798

Carrillo, J., Climent, N., Montes, M., Contreras, L.C., Flores-Medrano, E., Escudero-Ávila, D., Vasco-Mora, D., Rojas, N., Flores, P., AguilarGonzález, A., Ribeiro, M., \& Muñoz-Catalán, M.C. (2018). The Mathematics Teacher Specialized Knowledge (MTSK) model. Research in Mathematics Education 20(3), 236-253. https://doi.org/10.1080/14794802.2018.1479981

Clements, M. Bishop, A., Keitel, C., Kilpatrick, J., \& Leung, F. (2013). Third International Handbook of Mathematics Education. Springer.

Contreras, M. (2012). Problemas multiplicativos relacionados con la división de fracciones. Un estudio sobre su enseñanza y aprendizaje. Tesis doctoral), Universidad de Valencia, España.

English, L. D., \& Kirshner, D. (Eds.). (2015). Handbook of international research in mathematics education. Routledge.

Escudero-Ávila, D., Contreras, L., \& Vasco, D. (2016). Conocimiento de la enseñanza de la matemática (KMT). In J. Carrillo, L.C. Contreras, \& M. Montes (Eds.), Reflexionando sobre el conocimiento del profesor. Actas de las II Jornadas del Seminario de Investigación de Didáctica de la Matemática de la Universidad de Huelva (pp. 35-41). SGSE.

Flick, U. (2004). Introducción a la investigación cualitativa. Morata.

Flores, P. (2018). ¿Por qué multiplicar en cruz? Formación inicial de profesores de primaria en el área de Matemáticas. Unión. Revista Iberoamericana de Educación Matemática, 53, 9-29.

Flores-Medrano, E. (2015). Una profundización en la conceptualización de elementos del modelo de Conocimiento Especializado del Profesor de Matemáticas (MTSK) (Doctoral dissertation, Universidad de Huelva). 
Flores-Medrano, E. (2016). Conocimiento de la práctica matemática (KPM). In J. Carrillo, L.C. Contreras, \& M. Montes (Eds.), Reflexionando sobre el conocimiento del profesor. Actas de las II Jornadas del Seminario de Investigación de Didáctica de la Matemática de la Universidad de Huelva (pp. 30-34). SGSE.

Greer, B. (1992). Multiplication and division as models of situations. In D. A. Grouws (Ed.), Handbook of research on mathematics teaching and learning: A project of the National Council of Teachers of Mathematics (pp. 276-295). Macmillan.

Hernández, R., Fernández, C., \& Baptista, P. (2010). Metodología de la investigación. McGraw-Hill.

Lewin, R., López, A., Martínez, S., Rojas, D., \& Zanocco, P. (2014). Números. Recursos para la formación inicial de profesores de educación básica. SM.

Liñán, M.., Infante, J., \& Barrera, V. (2014). Conocimiento especializado de los estudiantes para maestro: la resolución de un problema de división de fracciones. Escuela Abierta, 14, 41-63.

Llinares, S., \& Sánchez, M. (1988). Fracciones, la relación parte todo. Síntesis

Ma, L. (2010). Knowing and teaching elementary mathematics: Teachers' understanding of fundamental mathematics in China and the United States. Routledge.

Moriel, J. (2014). Conocimientos especializados para enseñar división de fracciones. Tesis doctoral, Doctorado en Educación en Ciencias y Matemáticas, Universidad Federal de Mato Grosso, Cuiabá.

Nesher, P. (1992). Solving multiplication word problems. En G. Leinhardt, R. Putnam y Hattrup (Eds.). Analysis of arithmetic for mathematics teaching (pp. 189-219). Erlbaum.

Olanoff, D. (2011). Mathematical Knowlegde for Teaching Teachers: The Case of Multiplication and Division of Fractions. Thesis (Doctor of Matematics Education). Syracuse University, New York.

Özel, S. (2013). An Analysis of In-service Teachers' Pedagogical Content Knowledge of Division of Fractions. Anthropologist, 16 (1-2), 1-5. https://doi.org/10.1080/09720073.2013.11891330. 
Payne, J. (1976). Review of research on fractions. In Lesh, R. (Ed.), Number and measurement (vol. 1, pp. 145-188). University of Georgia.

Ramos-Rodríguez, E., Flores, P., \& Ponte, J. P. D. (2017). Práctica y reflexión de profesores de matemáticas chilenos bajo la perspectiva del estudio de clases. Quadrante, 26(2), 69-97. http://hdl.handle.net/10451/36442

Ribeiro, C. M. (2010). El desarrollo profesional de dos maestras inmersas en un grupo de trabajo colaborativo, a partir de la modelización de sus clases de matemáticas. Tesis doctoral, Universidad de Huelva, España.

Rico, L., Lupiáñez, J. L., \& Molina, M. (2013). El análisis didáctico en educación matemática. Metodología de investigación, innovación curricular y formación de profesores. Universidad de Granada.

Sanz, I., \& Martín, R. (2014). El estudio TEDS-M de la IEA en el marco del Instituto Nacional de Evaluación Educativa (INEE). In González, M. T., Codes, M., Arnau, D., \& Ortega, T. (eds.). Investigación en Educación Matemática XVIII (pp. 67-81). SEIEM.

Sfard, A. (2008). Thinking as communicating: human development, the growth of discourse, and mathematizing. Cambridge University Press.

Shulman, L. S. (1986). Those who understand: Knowledge growth in teaching. Educational researcher, 15(2), 4-14.

Tirosh, D. (2000). Enhancing prospective teachers' Knowledge of children's conceptions: The case of division of fractions. Journal for Research in Mathematics Education, 31(1), 5-25. https://doi.org/10.1007/s10857-005-5119-8

Valenzuela-Molina, M., \& Ramos-Rodríguez, E. (2018b). Conocimiento especializado identificado en problemáticas de enseñanza y aprendizaje de fracciones descritas por futuros profesores de educación básica. En XXXII Reunión Latinoamericana de Matemática Educativa (Relme 32). Colombia, Medellín.

Vergnaud, G. (1983). Multiplicative structures. In R. Lesh, \& M. Landau (Eds.), Acquisitions of mathematics concepts and processes (pp. 127174). Academy Press. 
Vergnaud, G. (1990). 13 - Développement et fonctionnement cognitifs dans le champ conceptuel des structures additives. In G. Netchine-Grynberg (Ed.), Développement et fonctionnement cognitifs chez l'enfant (pp. 261-278). Presses Universitaires de France. https://doi.org/10.3917/puf.netch.1990.01.0261

Vergnaud, G. (1997). The nature of mathematical concepts. In T. Nunes, \& P. Bryant (Eds.), Learning and teaching mathematics: An international perspective (pp. 5-28). Psychology Press/Erlbaum/Taylor \& Francis. 